\title{
Truths, Wounded Innocence, and the Post-truth Syndrome
}

\author{
Kent den Heyer, University of Alberta \\ Professor \\ Department of Secondary Education \\ University of Alberta \\ kdenheye@ualberta.ca
}

[W]hen I hear people denounce our political scene as "post-truth," I have to wonder when exactly they think it was that politics was determined by the truth? The same goes for those who decry today's "fake news." [...]To claim that with Trump's election we've entered a post-truth era of fake news is to claim that the U.S. was built on truthful politics and media. Political struggle isn't really about an existing truth but rather concerns the formulation of new truths and, more importantly, the materialization of those truths [...] The political project involves the power relations that compose truths, and the pedagogical project involves how we engage ourselves, each other, and the world in transformative processes. (Ford, 2018, paras. 1-4)

This quotation captures my concern with an emergent liberal nostalgia narrative, a type of wounded innocence, fashionable in response to what many see as a contemporary affliction affecting democratic institutions. According to this story, Trump and his administration have moved us into post-truth times. As definitive nostalgia, this posttruth narrative constructs a never existing political consensus that has now been lost, from the functioning of formal politics to truth claims found in the academe.

Laments aside, North American academic life has always suffered from an antiintellectual cultural strain. In the US context one can read historian Richard Hofstadter's (1963) Anti-intellectualism in American Life, Chris Lash's (1995) The Revolt of the Elites and The Betrayal of Democracy, also detailed by Susan Jacoby in her 2008 work The Age of American Unreason. In Canada, one can read the same claims in John Raulston Saul's Voltaire's Bastards (1992) and The Unconscious Civilization (1995) or John McMurtry's (1998) Unequal Freedoms: The global market as an ethical system, for example. One has to ask about those suffering post-truth syndrome, where have you been and what have you been reading?

I suspect that those who advance this narrative constitute that large part of the academe that have never taken white supremacy, imperialism, or patriarchy seriously as part of their scholarship or curriculum proposals. Now, they dispense that Trump, along with the unwitting support of pomo/poco/postructural scholarship (relevant distinctions between these orientations to analysis are seldom made), is to blame for the current tribulation. This is an odd claim given that those who cast it also assert that these forms of scholarship have had, at the same time, little discernable public impact.

As one example, Peter Seixas (2018) writes that "academics hardly needed to rally to defend the idea of truth because the only threat was from some of our own poststructuralist provocateurs, delivered in prose so tortured that it had little apparent impact on the broader public sphere" (p. 14). Yet, despite having little apparent impact, 
Seixas goes on to tell readers, "When the Trump administration began in 2017 with a flurry of unsubstantiated allegations and 'alternative facts' rhetoric, the game changed and the stakes were raised" (p. 14). In other words, the accused was never actually at the public scene of the crime and everyone actually at the scene is innocent of any contribution to what has transpired! Interesting logic.

Seixas (2018) continues, "The implications for history education and its scholars, internationally, are profound" (p. 14). How profound? "If we need to revisit our stances on the concept of truth, so too do we need to re-examine those on research and knowledge, interpretation and evidence, community and nation, identity and difference, and citizenship and solidarity" (p. 14). Yes, in fact, we do, exactly what the prose torturers, code for challenging desires for clarity on our already established terms, have been doing for 40 years! (Aoki, 2000). Furthermore, the Canadian TRC's "calls to action" specifically speak to the need for this "re-examination" both in our scholarly and public deliberations.

What has the liberal educational mainstream scholarship given us to combat the erosion of truth as they claim has occurred? Brain based best practices, calls for more resilient students and communities (in the face of structural poverty, racisms, patriarchy), flipping the system/school, critical thinking (lacking any critical theory based analysis), and STEM. This, along with calls for disciplinary based historical thinking in social studies returning again and again from the crypt of Jerome Bruner in which the words power, desire, justice, and the existential are as absent as is... truth. This liberal nostalgia serves to protect a wounded innocence by blaming others while those long cited mainstream educators continue to offer de-politicized proposals for K-16 curriculum that continue to do the wrong things, but, this time, better. It is as if some of us are intellectually ill prepared to recognize epistemological diversity, ethical imperatives, or basic political literacy about the primary function of liberal democracies to protect moneyed interests.

\section{Truths and Sophistry}

Two premises have grounded social studies since its inception and guide more recent curricular reforms. One is a belief that we exist in a democracy, however imperfect. Left out of this familiar framing are some harsh truths:

Trump [put] it plainly, that money is power, and power, ladies and gentlemen, is not self-sacrificing or democratic. Never was, never will be. Law unto itself, name of the game; nature of the beast. Not the exact words in Trump's loud and foul mouth, but the gist of the message that [a] fair enough share of his fellow citizens screamed, stamped, and voted in agreement because what he was saying they knew to be true [...] In the world according to Trump - as it was in the worlds according to Ronald Reagan, George Bush elder and younger, Bill Clinton, and Barack Obama - the concentration of wealth is the good, the true, and the beautiful. Democracy is for losers. The framers of the Constitution were of the same opinion. (Lapham, 2018, paras. 5-8) 
The second premise concerns engaging students in inter or cross disciplinary problem solving for current issues of concern by placing such in their historical, geographical, economic or political context(s). This premise, however, has always had to stand up against calls to socialize students into ideals of 'disciplinary reasoning' that will inculcate the kinds of thinking habits that will better this imperfect democracy. Disciplinary conventions, however abstracted, have never had anything to do with common idealizations of democracy as notable in the fact that the Soviet Union, North Korea, Nazi Germany and the contemporary plutocratic US all need(ed) top flight historians, teachers, engineers, economists, and the like to function. As long as these professionals leave questions of power out of their work, they can do as they wish and collect their awards.

People have diverse readings of power and desire as they play out in formal politics, the academe, and in what they propose for youth to study in schools. Whatever these readings may be, we must note the continued absence in historical thinking curriculum reform proposals of any call to provide youth with an explicit naming and investigation of desire, truth, or power. In the case of historical scholarship, this absence includes how these forces shape archives (Lalu, 2000), influences whose histories get distributed widely and in schools (and whose do not), and even in how historical thinking gets defined to exclude Indigenous understandings of such (Cutrara, 2018). The hypocrisy is, as my grandfather might say, a bit rich. In ignoring human conditions of desire, truths, and power, sophistry most accurately describes these proposals and our educational reality as it has long been before Trump ever left reality T.V.

\section{Long Past the Post}

Bartlett (2011) offers a most succinct set of distinctions between sophistry and a Socratic form of education: "The sophist, concerning the truth, must be a man of perspective rather than conviction, of judgment rather than thought, of interest and not principle" (p. 61).

As I have published and explored for 10 years, socialization and sophistry best describe the dominant vision of disciplinary based schooling today. These stand in contrast, not to citizenship or patriotism, but to the always-present potentiality of a Socratic form of the educational (Biesta, 2010; Biesta \& Safstrom, 2011; den Heyer, 2015). Whereas sophistry and socialization aim to empower students into an existing order of opinion, the educational begins precisely where such orders break down to instigate a "truth process" inaugurated by an "event" (Badiou, 2001). To work against such sophistries, I propose, again, a guiding curricular question, how might the forms of knowledge (those required for students to be considered qualified and socially competent) be arranged for the possibility of an "event" to occur and the educational in the form of a "truth process" inaugurated (Badiou, 2005; den Heyer, 2009; den Heyer, 2011; den Heyer, 2015; den Heyer \& Conrad, 2011)?

Let me provide some intellectual context for this claim. Doing so might help the reader understand the basis of my disregard for any argument that we have lost truth, rather than suffered wounded innocence, in a post-truth time. Badiou's (2001) first philosophical assertion is that "truth" ought to be the primary category of philosophy and that ethics, in contrast to its concern with "abstract categories (Man or Human, Right or 
Law, the Other ...), should be referred back to particular situations" (p. 3). Against any postmodern project, Badiou argues that when contemporary philosophy abandoned truth and elevated language as the object of its inquiry, it could no longer name or support an agent in the world to militate for justice (Badiou, 2001).

In a supporting role, the "best practices" that exemplify the modernist education project finally dropped Truth in favour of an uninspiring and self-justifying stance of procedural neutrality that can never even reasonably be the case as long as - as with history education - the nation-state's white supremacist grand narrative is assumed rather than questioned. This is also so if key concepts - power, desire, justice, the existential are discarded, as we subsequently encourage children to abandon truthful engagement with our histories and their lives. Rather, their arguments rest on a mutually supporting logic of student deficit on the one hand, and the philosophical abandonment of human inventive creativity on the other.

Against these positions, Badiou's (2001) "ethic of truths" is premised on "the strong, simple idea that every existence can one day be seized by what happens to it and subsequently devote itself to that which is valid for all" (p. 66). In this formulation, "seized" is designated as an "event," such as falling in love, that shatters any pre-existing intelligibility of self, other, or any topic at all. Thus seized, a "becoming subject" is bequeathed the opportunity to re-cognize new terms of understanding via a "truth process."

Badiou argues that truths are not achievements arrived at through predetermined techniques of reasoning, properties of power (that is, power only controls opinion, not truths), a quality of feeling, or facts temporally imprisoned by any dialectic (Balibar, 2004). Truths, rather, consist of the material traces of thinking/of thought expressed through love, art, science, and politics that a "becoming subject" produces through a truth process. Badiou argues that it is to these situated truth processes instigated by an event that ethics and philosophy (and, I assert, our curricular aims) must lend support. Several publications exist in North American history education and curriculum studies journals and books laying out Badiou's related vital concepts as they might play out in curriculum and pedagogy (e.g., den Heyer \& van Kessel, 2015). Given this, I must ask, what truth do post-truth commentators have in mind now that they have discovered the importance of truths, a topic about which to date they have had little to say?

Any mainstream academic educational engagement with this copious work on truths, however, will continue to be unlikely:

As with anything that constitutes an event, worlds are turned upside down, neuroses engendered, terrible beauties are born and education departments are forced to confront something that they are professionally required to find incomprehensible, namely, the desire to be educated, as something over and above the development of a specialist-knowledge, vocational competence, or the vague promotion of currently venerated "values." (Cooke, 2013, p. 3)

What to do? Refuse the easy pleasure of nostalgia; begin to read outside of dissertations' bibliographies; read Indigenous scholars whose work continues to be 
sidelined in disciplinary based scholarship. I offer other suggestions in Next Acts: Educational Impasse, events, and a one-legged magpie (den Heyer, 2018).

\section{References}

Aoki, D. S. (2000). The thing never speaks for itself: Lacan and the pedagogical politics of clarity. Harvard Educational Review, 70(3), 347-369. doi:10.17763/haer.70.3.83729226065nxq27

Badiou, A. (2001). Ethics: An essay on the understanding of evil (P. Hallward, Trans.). London, England: Verso.

Badiou, A. (2005). Handbook of inaesthetics (A. Toscano, Trans). Stanford, CA: Stanford University Press.

Balibar, E. (2004). The history of truth: Alain Badiou in French philosophy. In P. Hallward (ed.), Think again: Alain Badiou and the future of philosophy (pp. 21-38). London, England: Continuum.

Barlett, A. J. (2011). Badiou and Plato: An education by truths. Edinburgh, Scotland: Edinburgh University Press.

Bartlett, A. J., \& Clemens, J. (2012). Neither nor. Critical Inquiry, 38, 365-380. doi:10.1086/662747

Biesta, G. J. J. (2010). Good education in an age of measurement: Ethics, politics, democracy. London, England: Paradigm.

Biesta, G. J. J., \& Safstrom, C. A. (2011). A manifesto for education. Policy Futures in Education, 9(5), 540-547. doi:10.2304/pfie.2011.9.5.540

Cooke, B. (2013). "Declares by the void..." Parrhesia: A Journal of Critical Philosophy, 16, 77-101. Retrieved from http://www.parrhesiajournal.org/index.html

Cutrara, S. (2018). The settler grammar of Canadian history curriculum: Why historical thinking is unable to respond to the TRC's calls to action. Canadian Journal of Education, 41(1), 250-275. Retrieved from http://journals.sfu.ca/cje/index.php/cjerce/article/view/3156

den Heyer, K. (2009). Education as an affirmative invention: Alain Badiou and the purpose of teaching and curriculum. Educational Theory, 59(4), 441-463. doi:10.1111/j.1741-5446.2009.00330.x

den Heyer, K. (2011). History education as a disciplinary ethic of truths. In P. Clark (Ed.), New possibilities for the past: Shaping history education in Canada (pp. 154 172). Vancouver, BC: University of British Columbia Press.

den Heyer, K., \& Conrad, D. (2011). Using Alain Badiou's ethic of truths to support an 'eventful' social justice teacher education program. Journal of Curriculum Theorizing, 27(1), 7-19. Retrieved from http://journal.jctonline.org/index.php/jct/article/view/302

den Heyer, K. (2015). An analysis of aims and the educational event. Canadian Journal of Education, 38(1), 1-22. Retrieved from http://journals.sfu.ca/cje/index.php/cjerce/article/view/1717

den Heyer, K. (2017). A thinking education. Critical Education, 8(12), 1-8. Retrieved from https://ices.library.ubc.ca/index.php/criticaled/article/view/186203

den Heyer, K. (2018). Next acts: Educational impasse, events, and a one-legged magpie. Edmonton, AB: Alberta Teachers' Association. Retrieved from 
https://www.teachers.ab.ca/SiteCollectionDocuments/ATA/Publications/Research/ COOR-101-16\%20Next\%20Acts\%20Monograph_2018-08.pdf

den Heyer, K., \& van Kessel, C. (2015). Evil, agency, and citizenship education. McGill Journal of Education, 50(1), 1-18. doi:10.7202/1036107ar

Ford, D. (2018). Don't bring the truth to a knife fight: A new year's proposal for the left. Retrieved from http://www.hamptoninstitution.org/dont-bring-the-truth-to-a-knifefight.html\#.WvC2-yMrLzL

Hofstadter, R. (1963). Anti-intellectualism in American life. New York, NY: Vintage. Jacoby, S. (2008). The age of American unreason. New York, NY: Vintage.

Lalu, P. (2000). The grammar of domination and the subjection of agency: Colonial texts and modes of evidence. History and Theory. 39(4), 45-68. Retrieved from http://www.jstor.org/stable/2678049

Lapham, L. (2018). Due Process: Lamenting the death of the rule of law in a country where it might have always been missing. Retrieved from https://www.laphamsquarterly.org/rule-law/due-process

Lash, C. (1995). The revolt of the elites, and the betrayal of democracy. New York, NY: N.W. Norton \& Company, Inc.

McMurtry, J. (1998). Unequal Freedoms: The global market as an ethical system. Toronto, Canada: Garamond and Kumarian.

Saul, J. R. (1995). The unconscious civilization. New York, NY: Free Press.

Saul, J. R. (1992). Voltaire's bastards. New York, NY: Free Press.

Seixas, P. (2018). Forward. In S. Metzger \& L. McArthur Harris (Eds.), The Wiley international handbook of history teaching and learning (pp. 13-18). New York, NY: Wiley-Blackwell. 